\title{
GENUS ARCTOMYS, Gmel., Cuv.
}

DENTAL FORMULA.

$$
\text { Incisive } \frac{2}{2} ; \text { Canine } \frac{0-0}{0-0} ; \text { Molar } \frac{5-5}{4-4}=22 \text {. }
$$

Incisors strong, narrow, and wedge-shaped, anterior surface rounded; molars, with the upper surface thick and heavy.

Head large, mouth small, and placed below; eyes large, ears short, paws strong; fore-feet with four toes and the rudiment of a thumb; hind-feet with five toes; nails strong, compressed; tail bushy; no cheek pouches.

The name Arctomys, is derived from two Greek words : apxros, (arktos,) a bear, and $\mu \nu$, (mus,) a mouse.

There are, as far as we are informed, but eight known species of the genus as it is now defined, five on the Eastern Continent and three in North America.

\section{ARCTOMYS MONAX:-LinN.}

Wood-Chuck. Maryland Marmot. Ground-Hog.

PLATE II.-Female and Young.

A. Supra fusco cinereus, subtus sub-rufus, capite, cauda, pedibusque fuscis, naso et buccis cinereis.

CHARACTERS.

Brownish-gray above; head, tail, and feet, dark-brown; nose and cheeks ashy-brown, under surface reddish.

\section{SYNONYMES.}

Mus Monax, Linn., 12 ed., p. 81.

Maryland Marmot, Penn., Arct. Zool., vol. i., p. 111.

Monax, ou Marmotte de Canada, Buff., Supp. 111.

Maryland Marmot, Godman, Nat. Hist. vol. ii., p. 100, figure.

Maryland Marmot, Griffiths' Cuvier, vol. iii., p. 130, figure. 


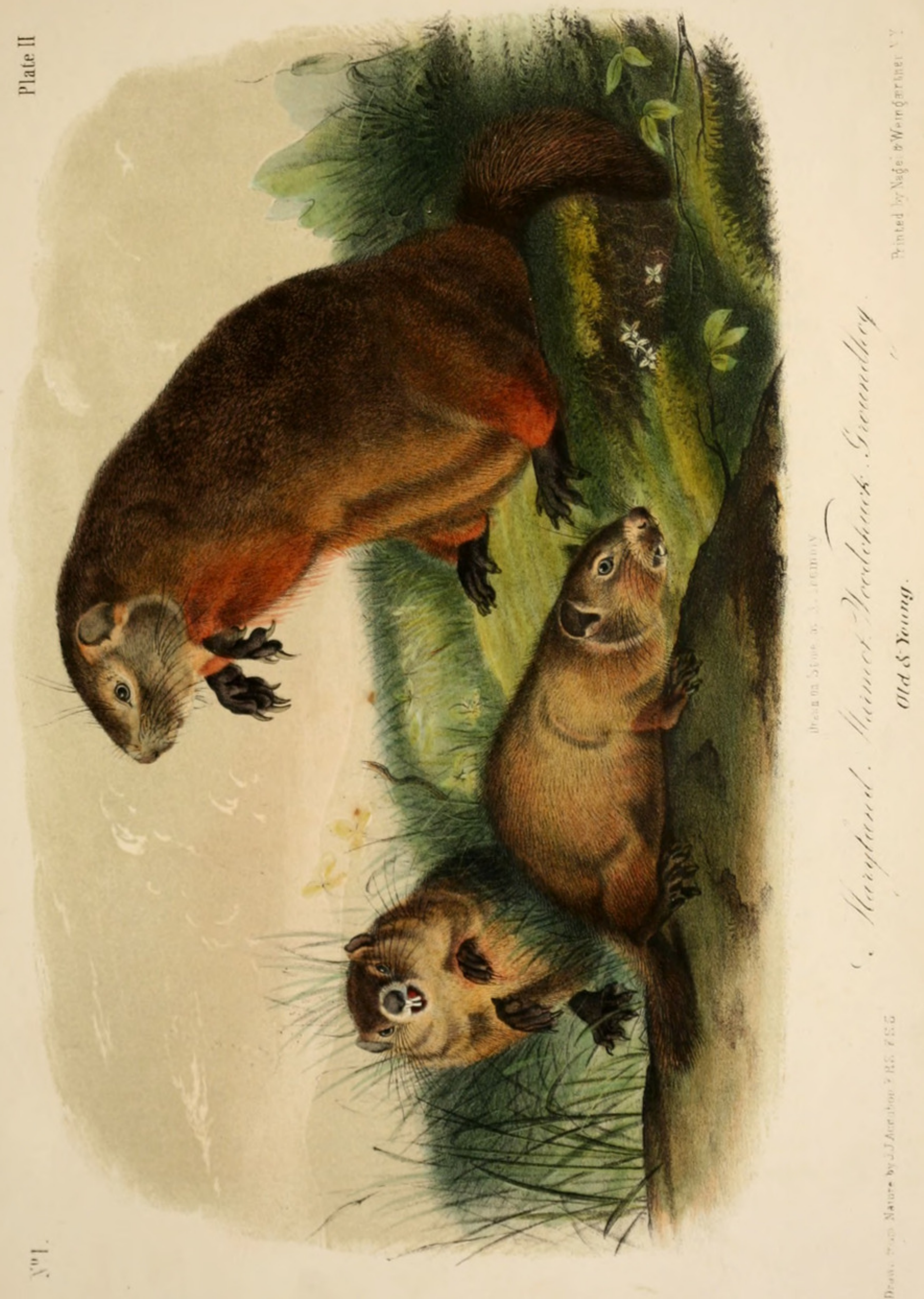



Quebec Marmot, Pennant, Hist. Quad., 1st ed., No. 259.

Mus Empetra, Pallas, Glir., p. 75.

Австомуя Empetra, Salt, Linn., Trans., vol. xiii., p. 24.

Австомys Empetra, Godman, Nat. Hist., vol. ii., p. 208.

Arotomys Monax, et Arctomys Empetra, Sabine, Trans. Linnæan Soc., vol. xiii., pp. $582,584$.

Arotomys Empetra, Richardson, Fauna Boreali Americana, p. 147, pl. 9.

\section{DESCRIPTION,}

The body is thick, and the legs are short, so that the belly nearly touches the ground. Head short and conical; ears short, rounded, and thinly clothed with hair on both surfaces; eyes moderate; whiskers numerous, extending to the ear; a membrane beneath the ears, on the posterior parts of the cheek, and a few setæ on the eye-brows; legs, short and muscular; fore-feet, with four toes, and the rudiment of a thumb, with a minute nail; hind-feet, with five toes. Toes long and well separated, palms naked, with tubercles at the roots of the toes. The middle toe longestthe first and third, which are nearly equal to each other, not much shorter; the extremity of the nail of the outer, extends only to the base of the nail of the adjoining toe; fore-claws moderately arched, obtuse and compressed; the soles of the hind-feet long, and naked to the heel ; hind-feet semi-palmated; nails channelled near the ends. Tail bushy, partly distichous; body clothed with soft woolly fur, which is mixed with coarse long hairs.

\section{COLOUR.}

This species (like the foregoing one) is subject to many variations in the colour of its fur, which may account perhaps for its numerous synonymes. We will, however, describe the animal in its most common colouring.

The finer woolly fur is for two-thirds of its length from the roots upwards, of a dark ashy brown, with the extremities light yellowish-brown. The long hairs are dark brown for two-thirds of their length, tipped sometimes with reddish white, but generally with a silvery white. The general tint of the back is grizzly or hoary ; cheeks, and around the mouth, light gray ; whiskers black; head, nose, feet, nails and tail, dark brown; eyes black. The whole under surface, including the throat, breast, belly, and the fore and hind legs, reddish orange.

The specimens before us present several striking varieties of colour; among them is one from Lower Canada, coal-black with the exception of the nose and a patch under the chin, which are light gray; the fur is short, and very soft; and the tail less distichous than in other varieties of this species. 
DIMENSIONS.

Adult Male.

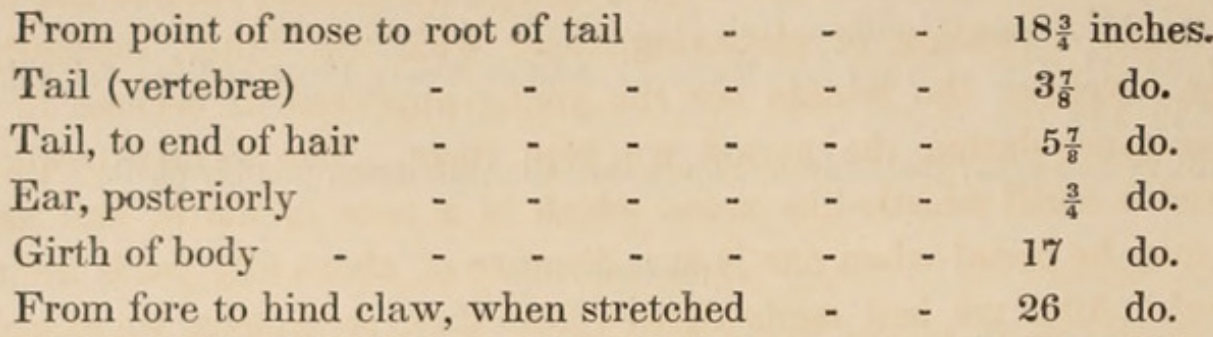

We have found some difference in the length of the tail, in different individuals, it being, in some speeimens, nearly seven inches long including the hair.

Weight 9lb. $11 \mathrm{oz}$.

HABITS.

In the Middle States many individuals of this species seem to prefer stony places, and often burrow elose to or in a stone wall. When this is the case, it is very difficult to procure them, as they are secure from the attacks of dogs, and much labour would be necessary in removing the large stones, and digging up the earth in order to dislodge them.

From our own observations, we are obliged to contradict the following account given of the habits of this species. It has been said that "when about to make an inroad upon a clover field, all the marmots resident in the vicinity, quietly and cautiously steal towards the spot, being favoured in their march by their gray colour, which is not easily distinguished.

"While the main body are actively engaged in cropping the clover heads, and gorging their 'ample cheek-pouches,' one or more individuals remain at some distance in the rear as sentinels. These watchmen sit erect, with their fore-paws held close to their breast, and their heads slightly inclined, to catch every sound which may move the air. Their extreme sensibility of ear enables them to distinguish the approach of an enemy long before he is sufficiently near to be dangerous, and the instant the sentinel takes alarm, he gives a clear shrill whistle, which immediately disperses the troop in every direction, and they speedily take refuge in their deepest caves. The time at which such incursions are made is generally about mid-day, when they are less liable to be interrupted than at any other period, either by human or brute enemies," (Godman, American Natural History, vol. ii., p. 102.)

We kept two of these animals alive for several weeks, feeding them on different grasses, potatoes, apples, and other fruits and vegetables. We found them to be very active at times, though fond of placing themselves 
in an erect posture, sitting on their rump, and letting their fore-legs and feet hang loosely down in the manner of our squirrels.

The old female, when approached, opened her mouth, showed her teeth, and made a rattling or clattering noise with the latter, evidently in anger. Neither the female nor the young appeared to become in any degree tame during the period we kept them. The former frequently emitted a shrill whistle-like noise, which is a note of alarm and anger, and may be heard when one is at a distance of about fifty yards from the animal. After we had made figures from those specimens, we examined their mouths, but did not find any pouches like those described by Dr. Godran, although there appeared to be a cavity, not larger than would admit a common green pea, and which was the only trace of any thing like a pouch in those we procured, and in all that have been observed by us.

When the Wood-Chuck is feeding, it keeps its erect position, inclining the head and fore-part of its body forward and sideways, so as to reach its food without extending the fore-legs and feet, which are drawn back under it; after getting a mouthful, it draws back its head again and brings its body to an upright posture by the muscular power of the hindlegs and feet. On being surprised or pursued, this species runs very fast for some eight or ten yards, and then frequently stops short and squats down close to the ground, watching to see if it has been observed; and will allow you to approach within a few feet, when it starts suddenly again, and again stops and squats down as before. Not unfrequently, under these circumstances, it hides its head beneath the dry leaves, or amid tufts of grass, to conceal itself from the pursuer. You may then generally capture or kill it with a stick. These animals bite severely, an defend themselves fiercely, and will, when unable to escape, turn and make battle with a dog of more than double their own size. Sometimes whilst they were lying down as if asleep, we have heard them make the clattering noise before spoken of, with their teeth; reminding us of a person's teeth chattering in an ague fit. When walking leisurely, they place their feet flat upon the ground at full length, arching the toes, however, as is the habit of squirrels. These Marmots sleep during the greater part of the day, stealing from their burrows early in the morning and towards evening. They climb trees or bushes awkwardly, and when they have found a comfortable situation in the sunshine, either on the branch of a tree, or on a bush, will remain there for hours. They clean their faces with the fore-feet, whilst sitting up on their hind-legs, like a squirrel, and frequently lick their fur in the manner of a cat, leaving the coat smoothed down by the tongue. The body of the Wood-Chuck is extremely flabby after being killed; its flesh is. however, tolerably good, 
although a little strong, and is frequently purchased by the humbler classes of people, who cook it like a roasting pig. Occasionally, and especially in autumn, it is exceedingly fat.

This species becomes torpid about the time the leaves have fallen from the trees in the autumn and the frosty air gives notice of the approach of winter, and remains burrowed in the earth until the grass has sprung up and the genial warmth of spring invites it to come forth.

We once observed one sunning itself at the mouth of its burrow, on the 23d of October, in the State of New-York; and in the same State, saw one killed by a dog on the first of March, when the winter's snow was yet lying in patches on the ground.

Where the nature of the country will admit of it, the Wood-Chucks select a projecting rock, in some fissure under which, they can dig their burrows. In other localities they dig them on the sides of hills, or in places where the surface of the ground is nearly level. These burrows or excavations are sometimes extended to the length of twenty or thirty feet from the opening; for the first three or four feet inclining obliquely downward, and the gallery being continued farther on, about on a level, or with a slight inclination upward to its termination, where there is a large round chamber, to which the occupants retire for rest and security, in which the female gives birth to her young, and where the family spend the winter in torpidity.

Concerning this latter most singular state of existence, we are gratified in being able to communicate the following facts, related to us by the Hon. Daniel W adsworth, of Hartford, Connecticut. "I kept," said he to us, "a fine Wood-Chuck in captivity, in this house, for upwards of two years. It was brought to me by a country lad, and was then large, rather wild, and somewhat cross and mischievous; being placed in the kitchen, it soon found a retreat, in which it remained concealed the greater part of its time every day. During several nights it attempted to escape by gnawing the door and window sills; gradually it became more quiet, and suffered itself to be approached by the inmates of the kitchen, these being the cook, a fine dog, and a cat; so that ere many months had elapsed, it would lie on the floor near the fire, in company with the dog, and would take food from the hand of the cook. I now began to take a particular interest in its welfare, and had a large box made for its use, and filled with hay, to which it became habituated, and always retired when inclined to repose. Winter coming on, the box was placed in a warm corner, and the Wood-Chuck went into it, arranged its bed with care, and became torpid. Some six weeks having passed without its appearing, or having received any food, I had it taken out of the box, and brought into the parlour; - it was inanimate, and as round as a ball, its 
nose being buried as it were in the lower part of its abdomen, and covered by its tail ; it was rolled over the carpet many times, but without effecting any apparent change in its lethargic condition; and being desirous to push the experiment as far as in my power, I laid it close to the fire, and having ordered my dog to lie down by it, placed the Wood-Chuck in the dog's lap. In about half an hour, my pet slowly unrolled itself, raised its nose from the carpet, looked around for a few minutes, and then slowly crawled away from the dog, moving about the room as if in search of its own bed! I took it up, and had it carried down stairs and placed again in its box, where it went to sleep, as soundly as ever, until spring made its appearance. That season advancing, and the trees showing their leaves, the Wood-Chuck became as brisk and gentle as could be desired, and was frequently brought into the parlour. The succeeding winter this animal evinced the same dispositions, and never appeared to suffer by its long sleep. An accident deprived me of my pet, for having been trodden on, it gradually became poor, refused food, and finally died extremely emaciated."

May we here be allowed to detain you, kind reader, for a few moments, whilst we reflect on this, one among thousands of instances of the all-wise dispensations of the Creator? Could any of the smaller species of quadrupeds, incapable, as many of them are, of migrating like the swift-winged inhabitants of the air to the sunny climes of the South, and equally unable to find any thing to subsist on among the dreary wastes of snow in the frost-bound lands of the North during winter, have a greater boon at the hands of Nature than this power of escaping the rigours and cold blasts of that season, and resting securely, in a sleep of insensibility, free from all cravings of hunger and all danger of perishing with cold, till the warm sun of spring once more calls them into life and activity? The Wood-Chuck and several other species of quadrupeds, whose organization in this respect differs so widely from general rules, may be said to have no winter in their year, but enioy the delightful weather of spring, summer, and autumn, without caring for the approach of that season during which other animals often suffer from both cold and hunger.

"Whilst hunting one day, (said a good friend of ours, when we were last in Canada,) I came across a Wood-Chuck, called in Canada by the different names of Siffleur, Ground-Hog, and occasionally Marmot, with a litter of six or seven young ones by her side. I leaped from my horse, feeling confident that I could capture at least one or two of them, but I was mistaken; for the dam, which seemed to anticipate my evil designs, ran round and round the whole of her young 'chucks,' 
urging them towards a hole beneath a rock, with so much quicknessenergy, I may call it-that ere I could lay hands on even one of her progeny, she had them all in the hole, into which she then pitched herself, and left me gazing in front of her well-secured retreat, thus baffling all my exertions!"

We have now and then observed this Marmot in the woods, leaning with its back against a tree and exposing its under parts to the rays of the hottest sun: on such occasions its head was reclining on its breast, the eyes were closed, the fore-legs hanging down, and it was apparently asleep, and presented a singular and somewhat ludicrous figure.

An intelligent naturalist has in his account of these animals, said that "their burrows contain large excavations in which they deposit stores of provisions." This assertion contradicts our own observation and experience. We are inclined to doubt whether storing up provisions at any or for any season of the year, can be a habit of this species. In the summer of 1814, in Rensselaer County, in the State of New-York, we marked a burrow which was the resort of a pair of Marmots. In the beginning of November the ground was slightly covered with snow, and the frost had penetrated to the depth of about half an inch. We now had excavations made in a line along the burrow or gallery of the Marmots; and at about twenty-five feet from the mouth of the hole, both of them were found lying close to each other in a nest of dried grass, which did not appear to have been any of it eaten or bitten by them. They were each rolled up, and looked somewhat like two misshapen balls of hair, and were perfectly dormant. We removed them to a hay stack, in which we made an excavation to save them from the cold. One of them did not survive the first severe weather of the winter, having, as we thought on examining them, been frozen to death. The other, the male, was now removed to a cellar, where he remained in a perfectly dormant state until the latter part of February, when he escaped before we were aware of his reanimation. We had handled him only two days previously, and could perceive no symptoms of returning vivacity. During the time he was in the cellar, there was certainly no necessity for a "store of provisions" for him, as the animal was perfectly torpid and motionless from the day he was caught, until, as just mentioned, he emerged from that state and made his escape.

In the month of May, or sometimes in June, the female brings forth her young, generally four or five in number. We have however on two occasions, counted seven, and on another eight, young in a litter. In about three weeks, they may be seen playing around the mouth of the 
burrow, where sitting on their hind-feet in the manner of the Kangaroo, they closely watch every intruder, retreating hastily into the hole at the first notes of alurm sounded by the mother.

The Wood-Chuck in some poritions of our country exists in considerable numbers, although it is seldom found associating with any of its own species except while the young are still unable to provide for themselves, until which period they are generally taken care of by both parents.

When the young are a few months old they prepare for a separation, and dig a number of holes in the vicinity of their early domicile, some of which are only a few feet deep and are never occupied. These numerous burrows have given rise to the impression that this species lives in communities, which we think is not strictly the case.

GEOGRAPHICAL DISTRIBUTION.

We have found the Wood-Chuck in every State of the Union north-east of South Carolina, and throughout the Canadas, Nova Scotia, and New Brunswick. We have also a specimen from Hudson's Bay; but perhaps it is nowhere more plentiful than on the upper Missouri River, where we found its burrows dug in the loamy soil adjoining the shores, as well as in the adjacent woods. It is not found in the maritime districts either of North or South Carolina, but exists very sparingly in the mountainous regions of those States. We have also traced it along the eastern range of the Rocky Mountains as far south as Texas. A Marmot exists in California resembling the present species very nearly, but which will probably prove distinct from the latter, a point which time and a greater number of specimens must determine.

GENERAL REMARKS.

It will be observed that we have united $A$. monax with $A$. empetra, and have rejected the latter as a species. This must necessarily follow from the fact, that if there is but one species, the name monax having been first given, must be retained. Schreber appears to have committed the first error in describing from a young specimen of a variety of $\boldsymbol{A}$. monax and erecting it into a new species. The old authors followed, and most of them being mere compilers, have constantly copied his errors. Mr. Sabine (Transactions Linn. Soc., vol. xiii., part 2, p. 584) described a specimen existing in the British Museum, as A. empetra, which we, after a careful examination, consider only a variety of $A$. monax. Mr. SABIne's description of the latter species is, as he informed us, compiled from various authors. Had he possessed a specimen, we think he would not 
have fallen into the common error. Dr. Richardsov, who appears not to have known the $A$. monax, also described it under the name of $A$. empetra, and gave a figure of it. We have, however, been unable to discover any specific differences between the specimens now before us and the one so accurately described and figured by him in the Faunaboreali-Americana. We are, therefore, compelled to consider them all as identical.

The great varieties of colour to be observed in different specimens of this Marmot, together with the circumstance that no two of them are of the same size, have tended no doubt to confuse those who have described it. We have seen them of all colours, from black to brown, and from rufous to bluish-gray, although they are most frequently of the colour represented in the plate. We have received a specimen from an eminent British naturalist as A. empetra, obtained from Hudson's Bay, which does not differ from the present species, and which instead of being eleven inches in length, the size given to $\mathrm{A}$. $\mathrm{em}$ petra, measures fifteen. As Richardson's species, moreover, was from seventeen to twenty inches in length, and as we compared his specimen (now in the museum of the Zoological Society of London) with several specimens of the Maryland Marmot, without observing the least specific difference between them, we consider it necessary to strike off the Canada Marmot, or Arctomys empetra, from the North American Fauna.

From the short and very unsatisfactory description, and the wretched figure of the Bahama Coney, contained in $\mathrm{C}_{\text {ATESBX}}$, vol. ii., p. 79, plate 79 , it is very difficult to decide either on the species or genus which he intended to describe. As however nearly all our writers on natural history have quoted his Bahama Coney as referring to the Maryland Marmot, we have carefully compared his descriptions and figure with this species, and have arrived at the conclusion that $\mathrm{C}_{\text {ATESBY }}$ described and figured one of the species of jutia, (Capromys Fournieri, Desm.,) and that his Cuniculus Bahamiensis has been therefore erroneously quoted as a synonyme of $A$. monax. 


\section{$2 \mathrm{BHL}$ Biodiversity Heritage Library}

Audubon, John James and Bachman, John. 1851. "Arctomys monax — Linn., Wood-Chuck - Maryland Marmot - Ground-Hog [PI. II, female and young]." The quadrupeds of North America 1, 16-24. https://doi.org/10.5962/p.322352.

View This Item Online: https://www.biodiversitylibrary.org/item/108513

DOI: https://doi.org/10.5962/p.322352

Permalink: https://www.biodiversitylibrary.org/partpdf/322352

\section{Holding Institution}

Duke University Libraries (archive.org)

\section{Sponsored by}

Duke University Libraries

\section{Copyright \& Reuse}

Copyright Status: Not provided. Contact Holding Institution to verify copyright status.

This document was created from content at the Biodiversity Heritage Library, the world's largest open access digital library for biodiversity literature and archives. Visit BHL at https://www.biodiversitylibrary.org. 